\title{
clinical evaluation of flurbiprofen adhesive plaster for osteoarthritis deformans
}

\author{
変形性膝関節症に対するフルルビプロフェン \\ 含有貼付剂の有用性
}

インドメタシン軟膏との比較
塩川優—*1), 青木虎吉*2), 七川歓次*3) 菅原幸子*4), 辻 陽雄 ${ }^{* 5)}$, 小川暢也*6)

\section{drug evaluation " var}

整形外科領域に沶いては, 変形性関節症, 肩関節周囲 炎, 腱・腱鞘炎などの持続性有痛疾患や, 外傷性の筋・ 骨・関節の障害のように, 疼痛を主訴とする疾患が治療 対象となる場合が多い。これらの疾患においては, 早期 に炎症の軽減を図って, 疾患の治癒を促進するとともに 患者の疼痛による苦痛を緩和する必要がある.

この目的に適ら治療の一つとして, 非ステロイド性抗 炎症・鎮痛剤の投与があげられるが，これら薬剤の内服 では，胃腸管障害などの副作用発現が多いといら難点が ある、そこで, 薬剤の投与経路変更に関する研究が進め られ，薬剤を経皮的に吸収させて，血液を介せず，炎症 局所へ直接浸透させる方法が考案された。

フルルビプロフェン含有貼付剂 (FP-A) は, フルルビ プロフェン (FP) を溶解状態で水性基剤中に分散させる ことによって，経皮吸収性を高めるべく研究開発された 製剤であり，ラット，モルモットなどの試験においては 直接浸透が認められるとともに，T $\max$ からみても持 続的な吸収が確認され，各種炎症モデルに対してすぐれ た抗炎症・鎮痛効果が認められた。 また，第 I 相試験に おいては, ヒトへの単回貼付による血漿濃度中の平均 $\mathrm{T} \max (\mathrm{hr})$ は13.8で内服時の約14倍, $\mathrm{C} \max (\mu \mathrm{g} / \mathrm{m} l)$ は

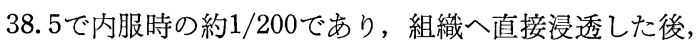
徐々に血中へ移行することが想定され，局所組織中への 直接浸透により局所的効果の持続性が示唆された ${ }^{14)}$.

一方, すでに非外傷性ならびに外傷性疼痛疾患を対象 とした非盲検臨床試験において, 高い有効率と安全性を 確認しており,さらに基剤を対照とした二重盲検交差試 験を, 変形性関節症, 肩関節周囲炎, 腱・腱鞘炎などの 持続性有痛疾患を対象として実施した結果, 基剤に比し て明らかに有意な有効性と, 基剤と同等の高い安全性が 確認されている5,6).

\footnotetext{
*1) 順天堂大学(名誉教授)

*2) 順天堂大学医学部整形外科学教室

*3) 滋賀医科大学医学部整形外科学教室

*4) 東京女子医科大学第二病院整形外科

*5) 富山医科薬科大学医学部整形外科学教室

*6) 愛媛大学医学部薬理学教室(コントローラー)
}

そこで今回は，FP-A の臨床上の有用性について，変 形性膝関節症を対象に，すでに市販されている経皮吸収 型抗炎症剤インドメタシン軟膏 (ID)を対照薬として比 較検討した。ただし，両薬剤は FP-A が貼付剂，ID が 軟高剂であって，明らかに剂型が異なり，二重盲検比較 試験の実施は不可能であるため, well controlled comparative study とした. FP-A は，すでに基剤との臨床 比較試験を実施して有意な有効性を確認しているので, 倫理的見地からも, 再び基剤投与群を設置する方法は避 けて 2 剂の比較試験とした。すなわち，医師が剤型によ って適応した患者を取捨選択しないための手段として， 両薬剤は，それぞれ外観上全く同一の包装箱に入れ，調 節品によって重量的にも同一としたらえで封印し、 コン トローラーが無作為に割り付けて，封筒法によって投与 薬剤を指定した，すなわち，医師が剤型によって適応し た患者を取捨選択しないための手段として，開封後に投 与順位を変更することを禁止し，投与順にコントローラ 一に報告することで患者を固定させ，さらに，施設ごと に試験例数よりも 1 例分ずつ多く薬剤を割り付けること で，最終開封まで薬剤の予測をできなくするなど，十分 な配慮と厳重なコントローラー管理のもとで実施し, 剂 型および使用法の異なる薬剤の比較試験においては現状 では最良の方法と考えられるものである.

以下に，本試験の方法と結果につき報告する.

\section{試験方法}

\section{(1) 対象症例}

昭和60年11月から昭和61年 2 月までに表 1 に示したな かの39施設で変形性膝関節症と診断された患者のうち, 片側に非ステロイド性抗炎症剂投与が適応と考えられる 症状があるもの，もしくは両側に症状があっても片側に 明らかな炎症症状, 疼痛症状を有するものを対象とし た。ただし，つぎに該当する患者はあらかじめ対象から 除くこととした.

(1) $\mathrm{X}$ 線上の変化が高度で, 薬物療法の効果が期待で きないもの

(2) 試験開始前 3 週間以内に経皮吸収型抗炎症鎮痛剂 
(インドメタシン軟膏，ステロイド軟膏)の使用経験があ るもの

(3) 試験開始前 1 週間以内に抗炎症鎮痛剂(坐剂を含 む)の投与を受けたもの

(4) 試験開始前 3 週間以内にステロイド風関節内注入 を行ったもの

(5) 狳布部に皮膚創, 皮膚炎を有するもの

(6) 出血性血液疾患など重篤な合併症を有するもの

(7) 薬物アレルギー歴のあるもの

(8) 皮膚の過敏症(軟膏，パップ剂，アルコールなど に対して)の既往歴のあるもの

(9) 関節液穿刺排液が,必要と予想されるもの

(10)妊婦叔よび授乳中の婦人

(11) 試験実施について同意が得られなかったもの

(12) 本試験についての理解が得られないもの

(13) その他, 担当医が本試験実施上不適当と判断した छの

(2) 試験薬剂

FP-A は， 1 枚 $\left(13.6 \times 10 \mathrm{~cm}^{2}\right.$, 高体 $\left.12 \mathrm{~g}\right)$ 中にフルル ビプロフェン $40 \mathrm{mg}$ を含有する貼付剤であり，ID は $1 \mathrm{~g}$ 中にインドメタシン $10 \mathrm{mg}$ を含有する黄色のゲル 軟膏である。したがって, 両薬剤は, 包装も内容もまっ たく異なるもので，外見上明らかに識別可能である。そ こで, 両薬剤をそれぞれ同形態の箱に収納し, 重さにつ いても調節品を箱内に同封することによって，同じとし て封印し，箱を開封しない限り外見上識別不可能とし た。
FP-A 投与群には 1 週間当り 2 袋 ( 1 袋中に FP-A 7 枚 入り，計 14 枚), ID 投与群には 1 週間当り $50 \mathrm{~g}$ 入りチ ェーブ 1 本をそれぞれ投薬するものとし，各 2 週間分を 1 症例分として前述の箱に収納した。その外見上の識別 不能性はコントローラーによって保証された。

薬剂の割り付けは, 1 組 7 症例分 (FP-A: 3 症例分, ID: 3 症例分, FP-A または ID: 1 症例分) とし, 前述 の外見上識別不可能とした箱に，コントローラーが 1 組 ごとに無作為に 1 番から 7 番までの一連番号を付すこと により行い, このらち，1番から6 番までについて試験 を実施することとした。

また，FP-A と ID の抜き取りサンプルについての規 格試験は，コントローラーが第三者機関 (千葉大学薬学 部薬効・安全性学講座薬物学研究室) に依頼し, 規格に 適合することが認められた。

(3) 投与方法

本試験に括いては，担当医が試験薬剂に対して患者を 無作為に選択するように，つぎの手順に従って投与し た。

(1) 試験薬剤につき，剂型のいかんに関わらず，いず れも十分に有効な成分が含まれている旨を説明して同意 を得た後, 薬剂が収納された箱に付された一連番号と同 一の番号を付した封筒(以下封筒と略称)を開封する。な お，必ず一連番号の若い順に開封する。

(2) 開封後速やかに封筒内の葉書（同一の一連番号な らびに剂型記載）に患者名, 試験開始年月日, 施設名な どを記入してコントローラー宛に発送し, 試験を開始す

表 1 参川施設

\begin{tabular}{|c|c|c|c|c|c|c|}
\hline 施 & 設 & 医師名 & 施 & 設 & 名 & 医師名 \\
\hline \multicolumn{2}{|c|}{ 浅香山病院整形外科* } & 中根勇平 & \multicolumn{3}{|c|}{ 市立貝塚病院整形外科 } & 田中稠久 \\
\hline \multicolumn{2}{|c|}{ 大阪警察病院整形外科 } & 水島哲也 & \multicolumn{3}{|c|}{ 市立川西病院整形外科 } & 広瀬一郎 \\
\hline \multicolumn{2}{|c|}{ 大阪鉄道病院整形外科 } & 大田＼cjkstart寛 & \multicolumn{3}{|c|}{ 市立堺病院整形外科* } & 本郷一郎 \\
\hline \multicolumn{2}{|c|}{ 大阪府立成人病センター整形外科 } & 小松原良雄 & \multicolumn{3}{|c|}{ 市立豊中病院整形外科 } & 鼓 敏光 \\
\hline \multicolumn{2}{|c|}{ 大阪労災病院リウマチ病科 } & 辻本正記 & \multicolumn{3}{|c|}{ 住友病院整形外科 } & 宮内寿彦 \\
\hline \multicolumn{2}{|c|}{ 河北総合病院整形外科 } & 真野 淳 & \multicolumn{3}{|c|}{ 聖マリアンナ医科大学整形外科学教室 } & 三好邦達 \\
\hline \multicolumn{2}{|c|}{ 関西労㷋病院整形外科 } & 赤堀 脩 & \multicolumn{3}{|c|}{ 千葉大学医学部整形外科学教室 } & 井上駿一 \\
\hline \multicolumn{2}{|c|}{ 関東遁信病院整形外科 } & 河井弘次 & \multicolumn{3}{|c|}{ 帝京大学医学部整形外科学教室 } & 立石昭夫 \\
\hline \multicolumn{2}{|c|}{ 北里大学医学部整形外科学教室 } & 山本 真 & \multicolumn{3}{|c|}{ 帝京大学付属清口病院整形外科 } & 三木 浩 \\
\hline \multicolumn{2}{|c|}{ 杏林大学医学部整形外科学教室 } & 河路 渡 & \multicolumn{3}{|c|}{ 東京女子医大第二病院整形外科 } & 菅原幸子 \\
\hline \multicolumn{2}{|c|}{ 群馬大学医学部整形外科学教室 } & 宇田川英一 & \multicolumn{3}{|c|}{ 東邦大学医学部整形外科学教室 } & 茂手木三男 \\
\hline \multicolumn{2}{|c|}{ 立川病院整形外科 } & 田中 守 & \multicolumn{3}{|c|}{ 独協医科大学整形外科学教室 } & 星野 孝 \\
\hline \multicolumn{2}{|c|}{ 国立大阪南病院整形外科 } & 前田 晃 & \multicolumn{3}{|c|}{ 富山医科薬科大学整形外科学教室 } & 辻 陽雄 \\
\hline \multicolumn{2}{|c|}{ 国立療養所刀根山病院整形外科 } & 膳 棟造 & \multicolumn{3}{|c|}{ 富山赤十字病院整形外科 } & 藤井保寿 \\
\hline \multicolumn{2}{|c|}{ 埼玉医科大学整形外科学教室 } & 東 博彦 & \multicolumn{3}{|c|}{ 富山労災病院整形外科 } & 飯田鷗二 \\
\hline \multicolumn{2}{|c|}{ 滋賀医科大学整形外科学教室 } & 七川歓次, 西岡淳一 & \multicolumn{3}{|c|}{ 日本赤十字医療センター整形外科 } & 蓮江光男 \\
\hline \multicolumn{2}{|c|}{ 順天堂大学医学部整形外科学教室* } & 青木虎吉 & \multicolumn{3}{|c|}{ 阪和泉北病院整形外科 } & 吉岡康裕 \\
\hline \multicolumn{2}{|c|}{ 順天堂伊豆長岡病院整形外科 } & 井上幸雄 & 堀木診療 & 形外 & & 堀木 篤 \\
\hline 昭和大学医 & 整形外科学教室 & 藤巻悦夫 & 三井記，心 & 整形 & & 加幡一彦 \\
\hline 昭和大学藤 & 病院整形外科 & 黒木良克 & 箕面市立 & 整形 & & 亀井正幸 \\
\hline 市立泉佐野 & 整形外科 & 岡山 孝 & 横浜南 & 邻完整 & & 山田勝久 \\
\hline
\end{tabular}

\footnotetext{
*印：症例なし
} 
る.ただし，封筒内の投薬指示票に記載された試験薬剂 の剤型について患者が拒否した場合は，脱落として処理 するものとし, 封筒内の葉書に患者名, 開封年月日, 施 設名とともにその旨を記載してコントローラー宛に発送 し，薬剤はそのまま保管する。

(3) 封筒開封後は，必ず指示された薬剤を当該患者に 投与する。な括，用法用量はつぎのと扤りとする。

i FP-A 投与群:FP-A については，1 日 2 回，原則 として起床時护よび就寝前に 1 回 1 枚を指定された患部 （膝）の一番痛いところを中心に貼付してネットで押さ 兄，次回の貼り替完時までそのまま貼りつづける。ただ し，入浴は貼り替光時に行う。

ii ID 投与群:ID そついては，1 日 $3 \sim 4$ 回，1回 約 $2 \mathrm{~g}$ (約 $6 \mathrm{~cm}$ )を指定された患部(膝)の一番痛いところ を中心に塗布し，指先で塗り広げる，入浴する場合は入 浴後に塗る.

(4) 再診時には，未使用あるいは使い残しの試験薬剂 はすべて持参させ，担当医が使用量を確認し，これを本 試験終了後回収するまで保管する。な括, 垪用薬剤, 併 用療法については, ステロイド剤, 抗炎症鎮痛剂(軟育, 坐剂などを含む)，パップ剤など試験薬剤の 効果判定に 影響のある薬風の併用は禁止し, 理学療法について子試 験開始前からの療法については継続とし，新たに開始し ないこととした。

(4) 臨床評価

(1) 評価時期および評価項目

臨床評価項目としては, 自発痛, 圧痛, 他動運動痛, 局所熱感, 運動制限, 膝蓋跳動・腫脹, 筋緊張につき, 試験開始時と投与 1 週間後拈よび 2 週間後に 4 段階 (3: 症状が高度．2:中等度． 1 : 軽度。 0 :症状なし) で評価し た。な怙，圧痛については終始同一部位で評価した。

臨床検查は, 血液検査 (赤血球数, 白血球数, へモ グロビン量), 血清生化学検查 (GOT, GPT, AL-P, BUN)，拉よび尿蛋白につき，試験開始時および投与 2 週間後に可能な限り実施した。な护，なんらかの理由で 試験を中止した場合は，その時点で可能な限り各評価項 目の判定および臨床検查を行った。

(2) 総合判定

i 医師の評価 (全般改善度): 同一患者については, 終始同一担当医師が，全般改善度（試験開始時と比較し て 1 週間後扣よび 2 週間後)を 7 段階 (1:著明改善. 2 :中 等度改善. 3 :軽度改善， 4 :不変． 5 :軽度悪化．6:中等度 悪化. 7:著明悪化)で評価した。

ii 最終全般改善度：試験終了時（2 週間後または中 止時)の全般改善度を最終全般改善度として記載した。

iii 患者の印象：試験開始時と比較して 1 週間後, 2 週間後の患者の 印象を 5 段階 (1: 非常に良くなった。 2 : 良くなった。 3 :やや良くなった。 4:変わらない。 5 :覀く
表 2 回収症例取扱い一覧表

\begin{tabular}{|c|c|c|c|c|}
\hline 区分 & FP-A & ID & 症 例 分 類 & \begin{tabular}{c|c|} 
例 背改安有 \\
景善全用 \\
数 度度度
\end{tabular} \\
\hline $\begin{array}{c}\text { 除外例 } \\
(13)\end{array}$ & 9 & 4 & $\begin{array}{l}\text { 治療歴違反 } \\
\text { (経皮消炎・鎮痛剤) } \\
\text { 治療歴違反 } \\
\text { (消炎・鎮痛剤) } \\
\text { 治療歴違反 } \\
\text { (ステロイド関節内注入) }\end{array}$ & $\begin{array}{l}2 \\
7 \\
4\end{array}$ \\
\hline $\begin{array}{c}\text { 脱落例 } \\
(27)\end{array}$ & 10 & 17 & $\begin{array}{l}\text { 初回以後来院せず } \\
\text { 併用薬違反 } \\
\text { 使用量不足 } \\
\text { 判定日違反 }\end{array}$ & $\left|\begin{array}{r|r}14 & 0 \\
3 & \bigcirc \\
1 & 0 \\
9 & 0\end{array}\right|$ \\
\hline $\begin{array}{c}\text { 評価例 } \\
(178)\end{array}$ & 92 & 86 & $\begin{array}{l}1 \text { 週値のみ評価 } \\
2 \text { 週値のみ評価 } \\
2 \text { 週目副作用来院せず } \\
\text { 完全症例 }\end{array}$ & \begin{tabular}{r|r|r|r}
29 & 0 & 0 & 0 \\
13 & 0 & 0 \\
1 & 0 & 0 \\
135 & 0 & 0
\end{tabular} \\
\hline 総症例 & 21 & & & \\
\hline
\end{tabular}

○印は評価採用を示寸。

なった)で評価させた。

I"iv 副作用・随伴症状：試験期間中に発現した全身的 または局所的随伴症状については, その種類, 程度, 発

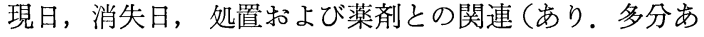
り。どちらともい壳ない，多分なし、なし)を記録した。 $\mathrm{v}$ 概括安全度: 試験期間中に発現した副作用・随伴 症状括よび臨床検査の異常值から総合的に判断し, 試験 薬剂の 概括安全度を 4 段階 (1:安全である，2:注淁安全 である．3:安全性に問題がある，4:安全でない)で評価 した.

vi 有用度 : 最終全般改善度に患者の印象之概括安全 度を加味して試験薬剤の有用度を 7 段階 $(1$ : 極めて有用. 2:有用．3:やや有用４：どちらともいえない５:やや好 ましくない，6:好ましくない７:極めて好ましくない） で評価した。

（5）追跡調查扣よび脱落・除外症例の取扱い

試験期間中に来院しなくなった患者には，できるだけ 速やかに電話または手紙で追跡調查を行った，脱落・除 外症例の取扱いに関しては, 全試験終了後の割り付け表 開封前に、コントローラーを含めた幹事会でデータを確 認しその取扱いを決定した。

（6）割り付け表の開封と解析

幹事会において脱落・除外症例の取扱いを決定した 後、コントローラーが割り付け表を開封した。解析につ いては，Mann-Whitney のU検定および $\chi^{2}$ 検定を用い て行った.

\section{試験結果}

(1) 対象症例

回収した症例の内訳については表 2 に示した。総回収 
表 3 背景因子

(1) 性 別

\begin{tabular}{c|c|c|c}
\hline 薬 剤 & 男 & 女 & $\chi^{2}$-test \\
\hline FP-A & 24 & 78 & NS \\
ID & 27 & 76 &
\end{tabular}

(2) 入院 - 外来

\begin{tabular}{c|r|r|c}
\hline 薬 剤 & 入院 & 外来 & $\chi^{2}$-test \\
\hline FP-A & 9 & 93 & NS \\
ID & 10 & 93 &
\end{tabular}

(3) 年 齢

\begin{tabular}{c|c|c|c|c|c|c|c|c}
\hline 薬 剂 & $30 \sim 39$ & $40 \sim 49$ & $50 \sim 59$ & $60 \sim 69$ & $70 \sim 79$ & $80 \sim 89$ & $\chi^{2}$-test & U-test \\
\hline FP-A & 1 & 12 & 27 & 29 & 29 & 4 & NS & NS \\
ID & 1 & 11 & 34 & 32 & 21 & 4 & &
\end{tabular}

(4) 重症度

\begin{tabular}{|c|c|c|c|c|c|}
\hline 薬 剂 & 軽 症 & 中等症 & 重 症 & $\chi^{2}$-test & U-test \\
\hline FP-A & 33 & 60 & 9 & \multirow{2}{*}{ NS } & \multirow{2}{*}{ NS } \\
\hline ID & 36 & 60 & 7 & & \\
\hline
\end{tabular}

(5) 現病歴

\begin{tabular}{c|c|c|c|c}
\hline 薬 剤 & $<1$ 月 & 1月 6月 & 6 月 $<$ & $\chi^{2}$-test \\
\hline FP-A & 22 & 45 & 34 & NS \\
ID & 29 & 46 & 28 & \\
\hline
\end{tabular}

表 4 症状别程度の分布

\begin{tabular}{|c|c|c|c|c|c|c|c|c|c|c|c|c|c|c|}
\hline 症状 & \multicolumn{2}{|c|}{ 自発痛 } & \multicolumn{2}{|c|}{ 圧 痛 } & \multicolumn{2}{|c|}{ 他動運動痛 } & \multicolumn{2}{|c|}{ 局所熱感 } & \multicolumn{2}{|c|}{ 運動制限 } & \multicolumn{2}{|c|}{$\begin{array}{l}\text { 膝蓋跳 } \\
\text { 動脹 }\end{array}$} & \multicolumn{2}{|c|}{ 笳緊張 } \\
\hline 評価 & FP-A & ID & FP-A & ID & FP-A & ID & FP-A & ID & FP-A & ID & FP-A & ID & FP-A & ID \\
\hline 症状なし（0) & 30 & 37 & 4 & 10 & 5 & 2 & 47 & 60 & 26 & 38 & 47 & 49 & 48 & 58 \\
\hline 軽 度 (1) & 38 & 36 & 40 & 35 & 37 & 44 & 42 & 35 & 42 & 43 & 33 & 32 & 46 & 39 \\
\hline 中等 度 (2) & 27 & 27 & 52 & 54 & 52 & 52 & 13 & 7 & 29 & 22 & 20 & 20 & 8 & 6 \\
\hline 高 度 (3) & 7 & 3 & 6 & 4 & 8 & 5 & 0 & 1 & 5 & 0 & 2 & 2 & 0 & 0 \\
\hline 計 & 102 & 103 & 102 & 103 & 102 & 103 & 102 & 103 & 102 & 103 & 102 & 103 & 102 & 103 \\
\hline$U$-test & \multicolumn{2}{|c|}{ NS } & \multicolumn{2}{|c|}{ NS } & \multicolumn{2}{|c|}{ NS } & \multicolumn{2}{|c|}{$\mathrm{NS}$} & \multicolumn{2}{|c|}{$\begin{array}{c}* \mathrm{FP}-\mathrm{A}>\mathrm{ID} \\
(\mathrm{Z}=2.31)\end{array}$} & \multicolumn{2}{|c|}{ NS } & \multicolumn{2}{|c|}{ NS } \\
\hline
\end{tabular}

$* \mathrm{P}<0.05$

症例218例中, FP-A 群は111例, ID 群は 107 例であっ た。このうち試験前治療歴から除外とした13例と, 初回 以後来院せずの 14 例と, 併用薬違反, 薬剂使用量不足な らびに判定日のずれなどで脱落となった13例を除く 178 例 (FP-A 群92例, ID 群86例) が有用度の, また, これ から副作用により 2 週間目終了以前に中止（1 週間後は 薬剂使用量不足で効果判定不可能)した 1 例を除く 177 例 (FP-A 群92例, ID 群85例) が最終全般改善度の解析対 象例となった。 また, 回収症例 218 例中, 1 週間後, 2 週間後ともに来院しなかった14例を除く FP-A 群104例, ID 群100例が概括安全度の解析対象例となった。

(2) 背景因子

対象患者の性別, 年齢, 入院・外来の別, 重症度括よ び現病歴については表 3 に示した. 年龄分布に打いて は, 50 歳以上の中高年が $87.8 \%$ を占め, 女性が多く (75.1\%)，汇とどが外来(90.7\%)であった。 また，重 症度では中等症以下が $92.2 \%$ 占め, 罹病期間は 6 力月 以内が $69.6 \%$ であったが，これら背景因子の各項目につ いて FP-A 群と ID 群に群間の偏りはみられなかった。
各症状の程度分布を表 4 に示した。試験開始日に自発 痛のあったものが FP-A 群には約 70\%, ID 群では約 65\%あったが， 痛扣よび他動運動痛は FP-A 群, ID 群ともに $90 \%$ 以上の高率に認められた。 自発痛, 圧痛, 他動運動痛, 局所熱感, 運動制限, 膝蓋跳動・腫脹およ び筋緊張の各項目についての検定の結果, 運動制限に拉 いて FP-A 群の症状が ID 群に比較して高度であった 以外, FP-A 群と ID 群に群間の偏りは認められなかっ た.

(3) 症状別改善度

1 週間後および 2 週間後の症状別効果については表 5 に示した。 自発痛, 正痛, 他動運動痛などの痛みに関す る各評価項目に扣いて，FP-A 群は1 週間後にそれぞれ $47.1 \% ， 45.9 \% ， 47.1 \%$ 改善がみられたのに対し, ID 群はそれぞれ $34.2 \%, 31.6 \% ， 35.4 \%$ あり，2 週 間後に扣いては，FP-A 群はそれぞれ $56.3 \% ， 66.3 \%$, $60.0 \%$ と改善されたのに対して, ID 群はそれぞれ 47.1 $\%, 52.2 \%, 52.9 \%$ 改善であった.この汪か, 運動制 限, 局所熱感, 膝蓋跳動・腫脹および䇗緊張の項目にお 
表 5 症状別改善度

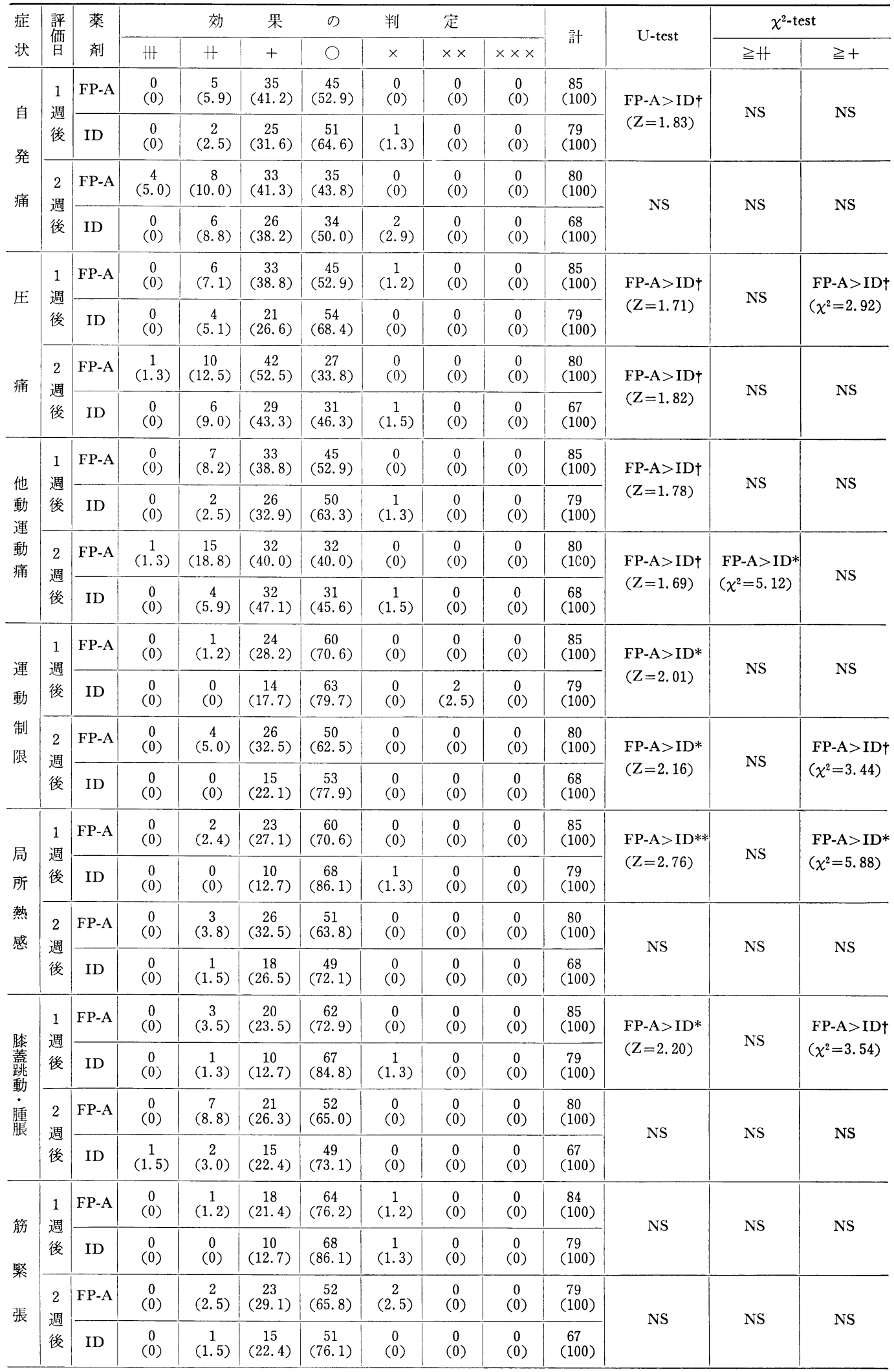

$\dagger \mathrm{P}<0.1 . * \mathrm{P}<0.05 . * * \mathrm{P}<0.01$ 
表 6 全般改善度（医師の評価）

\begin{tabular}{|c|c|c|c|c|c|c|c|c|c|c|c|c|c|c|}
\hline \multirow{2}{*}{$\begin{array}{l}\text { 評 } \\
\text { 価 } \\
\text { 日 }\end{array}$} & \multirow{2}{*}{$\begin{array}{l}\text { 薬 } \\
\text { 剂 }\end{array}$} & \multirow{2}{*}{$\begin{array}{l}\text { 著 } \\
\text { 明 } \\
\text { 改 } \\
\text { 善 }\end{array}$} & \multirow{2}{*}{$\begin{array}{l}\text { 中 } \\
\text { 等 } \\
\text { 度 } \\
\text { 䇾 }\end{array}$} & \multirow{2}{*}{$\begin{array}{l}\text { 軽 } \\
\text { 度 } \\
\text { 改 } \\
\text { 善 }\end{array}$} & \multirow{2}{*}{$\begin{array}{l}\text { 不 } \\
\text { 変 }\end{array}$} & \multirow{2}{*}{$\begin{array}{c}\text { 軽 } \\
\text { 度 } \\
\text { 悪 } \\
\text { 化 }\end{array}$} & \multirow{2}{*}{$\begin{array}{l}\text { 中 } \\
\text { 等 } \\
\text { 㕓 } \\
\text { 化 }\end{array}$} & \multirow{2}{*}{$\begin{array}{l}\text { 著 } \\
\text { 明 } \\
\text { 悪 } \\
\text { 化 }\end{array}$} & \multirow{2}{*}{ 計 } & \multirow{2}{*}{ U-test } & \multirow{2}{*}{$\begin{array}{c}\text { 有効率(\%) } \\
\text { 等度改善 }\end{array}$} & \multicolumn{3}{|c|}{$\chi^{2}$-test } \\
\hline & & & & & & & & & & & & ミ著明改善 & $\geqq$ 中等度改善 & 軽度改善 \\
\hline \multirow{2}{*}{$\begin{array}{l}1 \\
\text { 週 } \\
\text { 後 }\end{array}$} & FP-A & 8 & 24 & 31 & 22 & 0 & 0 & 0 & 85 & \multirow{2}{*}{$\begin{array}{l}\mathrm{FP}-\mathrm{A}>\mathrm{ID} * * \\
(\mathrm{Z}=3.29)\end{array}$} & 37.6 & \multirow{2}{*}{ NS } & \multirow{2}{*}{$\begin{array}{l}\text { FP-A }>\text { ID } * * \\
\left(\chi^{2}=9.41\right)\end{array}$} & \multirow{2}{*}{$\begin{array}{l}\text { FP-A }>\text { ID* } \\
\left(\chi^{2}=4.62\right)\end{array}$} \\
\hline & ID & 2 & 10 & 33 & 33 & 0 & 1 & 0 & 79 & & 15.2 & & & \\
\hline \multirow{2}{*}{$\begin{array}{l}2 \\
\text { 週 } \\
\text { 後 }\end{array}$} & FP-A & 17 & 33 & 19 & 11 & 0 & 0 & 0 & 80 & \multirow{2}{*}{$\begin{array}{l}\mathrm{FP}-\mathrm{A}>\mathrm{ID} * * \\
(\mathrm{Z}=2.77)\end{array}$} & 62.5 & \multirow{2}{*}{ NS } & \multirow{2}{*}{$\begin{array}{l}\mathrm{FP}-\mathrm{A}>\mathrm{ID}^{* *} \\
\left(\chi^{2}=9.82\right)\end{array}$} & \multirow{2}{*}{ NS } \\
\hline & ID & 11 & 13 & 27 & 15 & 1 & 1 & 0 & 68 & & 35.3 & & & \\
\hline
\end{tabular}

$* \mathrm{P}<0.05 . \quad * * \mathrm{P}<0.01$

表 7 患者の印象

\begin{tabular}{|c|c|c|c|c|c|c|c|c|c|c|c|c|}
\hline 評 & 薬 & $\begin{array}{l}\text { 非良 } \\
\text { 常之 }\end{array}$ & 良 & $\begin{array}{l}\text { や良 } \\
\text { や }\end{array}$ & 変 & 悪 & \multirow{2}{*}{ 計 } & \multirow{2}{*}{ U-test } & \multirow{2}{*}{$\begin{array}{c}\text { 有効率(\%) } \\
\text { ミ良くなった }\end{array}$} & \multicolumn{3}{|c|}{$x^{2}$-test } \\
\hline $\begin{array}{l}\text { 価 } \\
\text { 日 }\end{array}$ & 剂 & $\begin{array}{r}\text { にな } \\
\text { た }\end{array}$ & $\begin{array}{l}\text { な } \\
\text { た }\end{array}$ & $\begin{array}{l}\text { な } \\
\text { た }\end{array}$ & $\begin{array}{l}5 \\
\text { な } \\
w\end{array}$ & $\begin{array}{l}\text { な } \\
\text { た } \\
\text { た }\end{array}$ & & & & $\begin{array}{l}\text { き非常に } \\
\text { 良くった }\end{array}$ & ミ良くなった & $\begin{array}{l}\text { 良くやった } \\
\text { 年 }\end{array}$ \\
\hline 1 & FP-A & 15 & 20 & 37 & 13 & 0 & 85 & $\mathrm{FP}-\mathrm{A}>\mathrm{ID} * *$ & 41.2 & $\mathrm{FP}-\mathrm{A}>\mathrm{ID} * *$ & FP-A $>$ ID $* *$ & $\mathrm{FP}-\mathrm{A}>\mathrm{ID} * *$ \\
\hline 後 & ID & 2 & 11 & 40 & 24 & 2 & 79 & $(Z=3.96)$ & 16.5 & $(\chi$ & 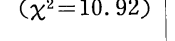 & ) \\
\hline 2 & FP-A & 20 & 32 & 21 & 7 & 0 & 80 & $\mathrm{FP}-\mathrm{A}>\mathrm{ID} * * *$ & 65.0 & NS & $\mathrm{FP}-\mathrm{A}>\mathrm{ID}^{* *}$ & FP-A $>$ ID $*$ \\
\hline 後 & ID & 12 & 14 & 25 & 15 & 2 & 68 & $(\mathrm{Z}=3.09)$ & 38.2 & & $\left(\chi^{2}=9.52\right)$ & $\left(\chi^{2}=6.00\right)$ \\
\hline
\end{tabular}

$* \mathrm{P}<0.05 . \quad * * \mathrm{P}<0.01$

いても, いずれも FP-A 群は ID 群にまさり, FP-A 群 の 1 週間後の改善は各項目とも, ID 群の 2 週間後の改 善にほ注相当する改善率が認められた。

\section{(4) 全般改善度}

1 週間後抒よび 2 週間後の医師の評価(全般改善度)に ついては, 表 6 に示した. 1 週間後に FP-A 群は著明 改善が9.4\%(8/85), 中等度改善以上が37.6\%(32/85)で あったのに対して，ID 群は著明改善が $2.5 \%(2 / 79)$, 中等度改善以上が $15.2 \%(12 / 79)$ であり，2 週間後には FP-A 群の著明改善は $21.3 \%(17 / 80)$, 中等度改善以上 は $62.5 \%(50 / 80)$ となり, ID 群は著明改善が $16.2 \%$ $(11 / 68)$, 中等度改善以上は $35.3 \%(24 / 68)$ であり， 1 週 間後， 2 週間後とも中等度改善以上では FP-A 群は, ID 群に比し有意にすぐれた改善率を示した。

(5) 患者の印象

1 週間後および 2 週間後の患者の印象については表 7 に示した。 1 週間後に「良くなった」以上の改善的印象 は, FP-A 群では $41.2 \%$ であったのに対して, ID 群 のそれは16.5\%で，また，2週間後においては FP-A 群 $65.0 \%$, ID 群 $38.2 \%$ の改善的印象であって, 患者の自 覚症状の改善においても，ID 群に比し著明にまさる結 果が示された.

(6) 最終全般改善度

最終全般改善度は表 8 に示したとおり，著明改善では FP-A 群が $22.8 \%(21 / 92)$, ID 群が $12.9 \%(11 / 85)$, 中 等度改善以上では FP-A 群が $63.0 \%(58 / 92)$, ID 群が
32.9\%(28/85) であり, FP-A 群と ID 群には最終全般 改善度に和いて明らかな差が認められた。

(7) 概括安全度ならびに副作用

概括安全度は表 9 に, 副作用の発現例については表 10 に示した。両群とも全身性の異常は認められず, 局所に 抢ける発赤, 皮疹, かゆみなどの皮膚症状が FP-A 群 に 3 例, ID 群に 9 例認められた. 症状の程度として は，FP-A 群では投与 1 週間内で一時的に中止したが, その後, 回復して 2 週間目の試験を行った 1 例を含め て, いずれも概括安全度は「ほぼ安全である(軽度の副作 用で処置を必要とせず試験薬剤の投与継続が可能であっ た)」と判定されたが，ID群に执いては「安全性に問題 がある (中等度の副作用で休薬やその他の処置を要し た）」と判定されたもの 3 例を含めて試験を中止したもの は 4 例であった。

(8) 臨床検査

概括安全度解析対象例中試験の前後とも臨床検查が実 施できた69例 (FP-A 群:37例. ID 群:32例)のうち, 検 查值中に異常值の認められた 8 例(FP-A 群: 4 例. ID 群：4 例) については表11に示した。

(9) 有用度

最終全般改善度に患者の印象，概括安全度を加味した 有用度については表12に示したと物り，「極めて有用」 は FP-A 群が23.9\%(22/92), ID 群が $11.6 \%(10 / 86)$, 「有用」以上では FP-A 群が $66.3 \%$ (61/92), ID 群が $32.6 \%(28 / 86)$ で FP-A 群と ID 群とには有用度におい 
表 8 最終全般改善度

\begin{tabular}{|c|c|c|c|c|c|c|c|c|c|c|c|c|c|c|c|}
\hline \multirow[b]{2}{*}{ 薬剂 } & \multicolumn{3}{|c|}{ 改 } & \multicolumn{2}{|l|}{ 善 } & \multicolumn{2}{|l|}{ 度 } & \multirow[b]{2}{*}{ 計 } & \multirow{2}{*}{ U-test } & \multicolumn{3}{|c|}{ 改善率 (\%) } & \multicolumn{3}{|c|}{$\chi^{2}$-test } \\
\hline & $\begin{array}{l}\text { 著明 } \\
\text { 改善 }\end{array}$ & $\begin{array}{l}\text { 中等度 } \\
\text { 改 善 }\end{array}$ & $\begin{array}{l}\text { 軽度 } \\
\text { 改善 }\end{array}$ & 不変 & $\begin{array}{l}\text { 軴度 } \\
\text { 悪化 }\end{array}$ & $\begin{array}{l}\text { 中等度 } \\
\text { 悪 }\end{array}$ & $\begin{array}{l}\text { 著明 } \\
\text { 悪化 }\end{array}$ & & & $\begin{array}{l}\text { 著明 } \\
\text { 改善 }\end{array}$ & $\begin{array}{l}\text { 等 } \\
\text { 度改善 }\end{array}$ & 㪕度 & $\begin{array}{l}\text { 著明 } \\
\text { 改善 }\end{array}$ & ミ中等度改善 & ミ軽度改善 \\
\hline FP-A & 21 & 37 & 22 & 12 & 0 & 0 & 0 & 92 & \multirow{2}{*}{$\begin{array}{l}\mathrm{FP}-\mathrm{A}>\mathrm{ID} * * \\
(\mathrm{Z}=3.96)\end{array}$} & 22.8 & 63.0 & 86.9 & \multirow{2}{*}{ NS } & \multirow{2}{*}{$\begin{array}{l}\mathrm{FP}-\mathrm{A}>\mathrm{ID}^{* *} \\
\left(\chi^{2}=14.84\right)\end{array}$} & \multirow{2}{*}{$\begin{array}{l}\mathrm{FP}-\mathrm{A}>\mathrm{ID}^{* *} \\
\left(\chi^{2}=8.89\right)\end{array}$} \\
\hline ID & 11 & 17 & 29 & 25 & 2 & 1 & 0 & 85 & & 12.9 & 32.9 & 67.1 & & & \\
\hline
\end{tabular}

$* * \mathrm{P}<0.01$

表 9 概括安全度

\begin{tabular}{|c|c|c|c|c|c|c|c|}
\hline \multirow[b]{2}{*}{ 薬 剂 } & \multirow[b]{2}{*}{$\begin{array}{l}\text { 副 } \\
\text { 作 } \\
\text { 用 } \\
に \\
\text { 対 } \\
\text { す } \\
\text { る } \\
\text { 処 } \\
\text { 置 }\end{array}$} & \multicolumn{2}{|c|}{ 判 } & \multicolumn{2}{|c|}{ 定 } & \multirow[b]{2}{*}{ 計 } & \multirow[b]{2}{*}{$\begin{array}{l}\text { 合 } \\
\text { 計 }\end{array}$} \\
\hline & & $\begin{array}{l}1 \\
\text { 安 } \\
\text { 全 } \\
\text { で } \\
\text { あ } \\
\text { る }\end{array}$ & $\begin{array}{l}2 \\
\text { 湴 } \\
\text { ぼ } \\
\text { 安 } \\
\text { 全 } \\
\text { で } \\
\text { あ } \\
\text { る }\end{array}$ & $\begin{array}{l}3 \\
\text { 安 } \\
\text { 全 } \\
\text { 性 } \\
\text { に } \\
\text { 問 } \\
\text { 題 } \\
\text { が } \\
\text { あ } \\
\text { る }\end{array}$ & $\begin{array}{l}4 \\
\text { 安 } \\
\text { 全 } \\
\text { で } \\
\text { な } \\
\text { い }\end{array}$ & & \\
\hline \multirow{2}{*}{ FP-A } & 継続 & 101 & 2 & 0 & 0 & 103 & \multirow{2}{*}{104} \\
\hline & 中止 & 0 & $1^{*}$ & 0 & 0 & 1 & \\
\hline \multirow{2}{*}{ ID } & 継続 & 91 & 5 & 0 & 0 & 96 & \multirow{2}{*}{100} \\
\hline & 中止 & 0 & 1 & 3 & 0 & 4 & \\
\hline
\end{tabular}

*一時中止し,その後継続
表 10 副作用

\begin{tabular}{|c|c|c|c|c|c|c|c|}
\hline No. & 薬剂 & $\begin{array}{l}\text { 薬 } \\
\text { 剂 } \\
\text { 番 } \\
\text { 号 }\end{array}$ & $\begin{array}{l}\text { 概 } \\
\text { 括 } \\
\text { 安 } \\
\text { 全 } \\
\text { 度 }\end{array}$ & 作 & 度 & 処 & $\begin{array}{l}\text { 薬 } \\
\text { 剤 } \\
\text { c } \\
\text { 品 } \\
\text { 関 } \\
\text { 係 }\end{array}$ \\
\hline 1 & & $3-3$ & 2 & 局：かぶれ & 軽 & 継続 & 有 \\
\hline 2 & FP-A & $15-1$ & 2 & 局 : 発赤湿疹 & 中 & 継続 & 有 \\
\hline 3 & & $16-2$ & 2 & 局：皮疹 & 軽 & 中止 & 有 \\
\hline 1 & & $4-4 *$ & 2 & 局 : かぶれ & 軽 & 中止 & 有 \\
\hline 2 & & $7-4$ & 2 & 局：かゆみ & 軽 & 継続 & 有 \\
\hline 3 & & $9-5$ & 3 & 局：発瘆 & 中 & 中止 & 有 \\
\hline 4 & & $11-2$ & 3 & 局：かゆみ, 皮疹 & 高 & 中止 & 有 \\
\hline 5 & ID & $20-1$ & 2 & 局：色素沈着 & 軽 & 継続 & 有 \\
\hline 6 & & $26-6$ & 2 & 局：かぶれ & 軽 & 継続 & 有 \\
\hline 7 & & $35-1$ & 3 & 局：皮疹 & 高 & 中止 & 有 \\
\hline 8 & & $36-2$ & 2 & 局：皮膚炎，発赤，かゆみ & 軽 & 継続 & 有 \\
\hline 9 & & $36-3$ & 2 & 局：発赤, かゆみ & 軽 & 継続 & 有 \\
\hline
\end{tabular}

*除外例

表 11 臨床検査の異常值

\begin{tabular}{|c|c|c|c|c|c|c|c|}
\hline & & \multicolumn{3}{|c|}{ FP-A } & \multicolumn{3}{|r|}{ ID } \\
\hline & & $\begin{array}{c}\text { 薬剤 } \\
\text { No. }\end{array}$ & 検査值 & 定 & $\begin{array}{l}\text { 薬剤 } \\
\text { No. }\end{array}$ & 検査值 & 定 \\
\hline 赤血球数 & $\left(\times 10^{4}\right)$ & $30-5$ & $346 \rightarrow 353$ & 薬剂との因果関係なし & $30-6$ & $381 \rightarrow 333$ & 薬剂との因果関係なし \\
\hline \multicolumn{2}{|l|}{ 白血球数 } & $30-5$ & $3300 \rightarrow 3100$ & 薬剤との因果関係なし & $30-6$ & $2600 \rightarrow 3300$ & 薬剂との因果関係なし \\
\hline \multicolumn{2}{|c|}{ ヘモグロビン $(\mathrm{g} / \mathrm{d} l)$} & $30-5$ & $10.6 \rightarrow 10.6$ & 薬剤との因果関係なし & $30-6$ & $12.2 \rightarrow 10.4$ & 薬剂との因果関係なし \\
\hline AL-P & $\begin{array}{l}\text { 比色法 } \\
\mathrm{K}-\mathrm{A} \text { 法 } \\
10 / l \text { 法 }\end{array}$ & $\begin{array}{r}9-3 \\
- \\
36-1 \\
\end{array}$ & $\begin{array}{l}109 \rightarrow 123 \\
357 \rightarrow 375\end{array}$ & $\begin{array}{c}\text { 薬剤との因果関係なし } \\
\text { 薬剤との因果関係なし }\end{array}$ & $\begin{array}{r}9-1 \\
30-6 \\
- \\
\end{array}$ & $\begin{array}{l}113 \rightarrow 101 \\
9.8 \rightarrow 11.5 \\
-\end{array}$ & $\begin{array}{c}\text { 薬剂との因果関係なし } \\
\text { 薬剤との因果関係なし } \\
\text { - }\end{array}$ \\
\hline \multicolumn{2}{|l|}{ BUN } & $\begin{array}{r}9-3 \\
-\end{array}$ & $\stackrel{15 \rightarrow 19}{-}$ & $\begin{array}{l}\text { 薬戍との因果関係多分 } \\
\text { なし }\end{array}$ & $\begin{array}{r}9-4 \\
13-1\end{array}$ & $\begin{array}{c}26 \rightarrow 22 \\
15.2 \rightarrow 18.7\end{array}$ & $\begin{array}{l}\text { 薬剤との因果関係なし } \\
\text { 楽剤との因果関係どちらともいえない }\end{array}$ \\
\hline \multicolumn{2}{|l|}{ 尿蛋白 } & $4-2$ & $+2 \rightarrow+3$ & 薬剤との因果関係なし & $9-4$ & $? \rightarrow+2$ & 薬剂との因果関係多分なし \\
\hline
\end{tabular}

表 12 有用度

\begin{tabular}{|c|c|c|c|c|c|c|c|c|c|c|c|c|c|c|c|}
\hline \multirow[b]{2}{*}{ 薬荗 } & \multicolumn{3}{|c|}{ 有 } & \multicolumn{2}{|c|}{ 用 } & \multicolumn{2}{|c|}{ 度 } & \multirow[b]{2}{*}{ 計 } & \multirow{2}{*}{ U-test } & \multicolumn{3}{|c|}{ 有用率(\%) } & \multicolumn{3}{|c|}{$\chi^{2}$-test } \\
\hline & \begin{tabular}{|l} 
極めて \\
有
\end{tabular} & 有用 & や户 & $\begin{array}{l}\text { どちら } \\
\text { とし } \\
\text { えない }\end{array}$ & $\begin{array}{l}\text { pや好 } \\
\text { まL< } \\
\text { ない }\end{array}$ & $\begin{array}{l}\text { 子好まし } \\
\text { くない }\end{array}$ & $\begin{array}{l}\text { 極めて } \\
\text { 好まし } \\
\text { くない }\end{array}$ & & & 引極め & 有用 & 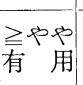 & $\begin{array}{l}\text { 極めて } \\
\text { 有 }\end{array}$ & 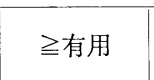 & ミやや有用 \\
\hline FP-A & 22 & 39 & 17 & 14 & 0 & 0 & 0 & 92 & \multirow{2}{*}{$\begin{array}{c}\text { FP-A }>\text { ID*** } \\
(\mathrm{Z}=4.30)\end{array}$} & 23.9 & 66.3 & 84.8 & \multirow{2}{*}{$\begin{array}{l}\text { FP-A }>\text { ID } \dagger \\
\left(\chi^{2}=3.75\right)\end{array}$} & \multirow{2}{*}{$\begin{array}{r}\mathrm{FP}-\mathrm{A}>\mathrm{ID} * * \\
\left(\chi^{2}=18.92\right)\end{array}$} & \multirow{2}{*}{$\begin{array}{l}\text { FP-A }>\text { ID** } \\
\left(\chi^{2}=7.33\right)\end{array}$} \\
\hline ID & 10 & 18 & 29 & 22 & 5 & 2 & 0 & 86 & & 11.6 & 32.6 & 66.3 & & & \\
\hline
\end{tabular}

$\dagger \mathrm{P}<0.1 . \quad * \mathrm{P}<0.05 . \quad * * \mathrm{P}<0.01$ 
ても明らかな差が認められた。

\section{考 察}

非ステロイド性抗炎症鎮痛薬である FP(フルルビプ ロフェン)は, 整形外科領域に拈ける疼痛疾患に対し， 高い有效性を有するが，一般的に，この種の薬剤が有す る胃腸管障害については FP においても例外ではない。 そこで薬剂を胃腸管や血流を介さず直接に皮膚へ適用し て, 皮下の炎症局所へ浸透せしめ, 安全でかつ効率の上 い治療を行らことを目的に FP の貼付剂 FP-A が考案 された。

FP-A そついては, すでそ動物実験的にも臨床的にも その吸収性, 有効性, 安全性が確認され, 特に基剤との 二重盲検交差試験に打いては，基剤に対し明らかに有意 差をもって有効性が認められているが，同種同効の市販 品との比較のために，今回は整形外科領域に和ける慢性 疼痛性疾患であり, 比較的症例数の多い変形性膝関節症 を対象として,インドメタシン軟膏との臨床比較試験を 行った.

本試験は前述したように，比較すべき両薬剂が外観上 も使用法も本質的に違っているために, 薬剤の識別性を できる限りなくすようにエ夫して，コントローラーに よる厳重な管理のもとで well controlled comparative study として実施された。 対象患者の背景因子に関し, 両薬剤間に群間の偏りがなかったことから，患者の無作 為的選択については十分に成功したものと考兄られる。

総回収症例 218例中, 改善度解析対象例数は FP-A 群 92例, ID 群 85 例であり, 概括安全度解析対象例数は FP-A 群104例, ID 群 100 例で, 回収例数, 解析対象例 数ともに両薬剤群に汇とんど差はなく，本試験の実施な らびに判定に括ける公平性は十分なものであったと判断 される。

解析結果によれば, FP-A 群の最終全般改善度は著明 改善が $22.8 \%$, 中等度改善以上では $63.0 \%$ と高く, ま た，全身性副作用の発現はなく，貼付部位における発 赤, 皮疹, かゆみなどの軽度の皮膚症状が 104 例中 3 例 飞認められたのみで, 問題となるような臨床検查值の異 常や変動もなかったことから，有用度に特いては「極め て有用」が23.9\%,「有用」以上が $66.3 \%$ に至った。症状 別に改善度をみた場合, 特に自発痛, 压痛, 他動運動痛 などの痛みの症状に対して，FP-A 群は 1 週間後にそれ ぞれ47\%，46\%，47\%，2 週間後に56\%，66\%，60\%の 改善率を示し， 1 週間後にすで高い改善率が認めら れ，その後も改善率が高まっていることは，FP-A に上 りこれらの症状に対する早期改善効果が示唆され, 治療
期間の短縮が期待される.

一方, FP-A 群中の 3 例に「接着が良い」との記載があ り「かぶれなくてよい」、「運動制限が少なくてよい」を 含めて貼り心地のよさについて記載されたものが 6 例あ った，FP-A は，患者の使用感からの有用性も高いもの と考えられ，安全で効率がよいうえに患者の貼付剂に対 する抵抗感も少なく，長期連用にも耐光得る有用性の高 い局所療法剤であろらと考觉られる。

\section{結 語}

FP-A の変形性関節症に招ける有用性を評価する目的 で, 対象疾患を変形性膝関節症とし，すでに市販されて いる同種同効品インドメタシン軟膏 (ID)を対照薬とし て,多施設共同による well controlled comparative study を，特にきびしく管理された封筒法により実施してつぎ の結果を得た。

(1) 全般改善度, および最終全 般改善度, 患者の印 象, 各症状別改善度に怙いて, FP-A 群は ID 群に比 し，有意にすぐれた改善度を示した。

(2) 自発痛, 压痛, 他動運動痛など各症状に扔いて, FP-A 群は, 比較的早期に症状の改善がみられ, ID 群 に比し有效性が明らかであった。

(3) FP-A 群の副作用は, 症例の $2.9 \%$ ( 3 例) 亿軽度 の貼付部発赤, 皮疹, かゆみなどがみられたのみで, ID 群よりも低率であり，FP-A の高い安全性が確認さ れた。

(4) FP-A 群は, ID 群に比し有意に高い有用性を示 した.

\section{文 献}

1）坂井康男・他：ラット皮虐に適用した Flurbiprofen(FP)の吸収, 分布, 代謝及び排泄。医薬品 研究 13(3): 815, 1982.

2）北川晴雄・他：Flurbiprofen の皮膚適用に上る抗 炎症・鎮痛作用及び皮虞刺激試験。医薬品研究 13(4): 869, 1982.

3）外本省三・他: Flurbiprofen 外用剤 (FP-A) の抗 炎症作用。医藤品研究 13(4): 879, 1982.

4）清水正啓・他：FP-A 第 I 相臨床試験一健康成人 Volunteer に上る忍容性及び血中濃度の検討。未 発表

5）平沼 晃・他：外傷性拉上び非外傷性炎症疾患儿 対するフルルビプロフェン含有貼付剤アドフロべ ンの臨床効果. 薬理と治療 10(6)：3645, 1982.

6）七川歓次・他：整形外科領域に括村るフルルビプ ロフェン含有貼付剤アドフロベンの臨床試験に上 る基剤との比較。炎症 3(1)：1，1983. 